\title{
TU/e EnNHOUN

\section{Reaction of small olefins on zeolite H-ZSM-5. A thermogravimetric study at low and intermediate temperatures}

\section{Citation for published version (APA):}

Berg, van den, J. P., Wolthuizen, J.P., \& Hooff, van, J. H. C. (1983). Reaction of small olefins on zeolite H-ZSM5. A thermogravimetric study at low and intermediate temperatures. Journal of Catalysis, 80(1), 139-144. https://doi.org/10.1016/0021-9517(83)90238-5

DOI:

10.1016/0021-9517(83)90238-5

Document status and date:

Published: 01/01/1983

\section{Document Version:}

Publisher's PDF, also known as Version of Record (includes final page, issue and volume numbers)

\section{Please check the document version of this publication:}

- A submitted manuscript is the version of the article upon submission and before peer-review. There can be important differences between the submitted version and the official published version of record. People interested in the research are advised to contact the author for the final version of the publication, or visit the $\mathrm{DOI}$ to the publisher's website.

- The final author version and the galley proof are versions of the publication after peer review.

- The final published version features the final layout of the paper including the volume, issue and page numbers.

Link to publication

\section{General rights}

Copyright and moral rights for the publications made accessible in the public portal are retained by the authors and/or other copyright owners and it is a condition of accessing publications that users recognise and abide by the legal requirements associated with these rights.

- Users may download and print one copy of any publication from the public portal for the purpose of private study or research.

- You may not further distribute the material or use it for any profit-making activity or commercial gain

- You may freely distribute the URL identifying the publication in the public portal.

If the publication is distributed under the terms of Article 25fa of the Dutch Copyright Act, indicated by the "Taverne" license above, please follow below link for the End User Agreement:

www.tue.nl/taverne

Take down policy

If you believe that this document breaches copyright please contact us at:

openaccess@tue.nl

providing details and we will investigate your claim. 


\title{
Reaction of Small Olefins on Zeolite H-ZSM-5. A Thermogravimetric Study at Low and Intermediate Temperatures
}

\author{
J. P. van den Berg, J. P. Wolthuizen, and J. H. C. van HoofF \\ Laboratory for Inorganic Chemistry, Eindhoven University of Technology, P.O. Box 513, \\ $5600 \mathrm{MB}$ Eindhoven, The Netherlands
}

Received November 24, 1981; revised July 15, 1982

\begin{abstract}
Oligomerization and cracking reactions of ethene, propene, and isobutene on zeolite H-ZSM-5 (300 $\leq T<600 \mathrm{~K}$ ) were investigated using temperature-programmed adsorption and desorption experiments, high-resolution ${ }^{13} \mathrm{C}$-NMR spectroscopy, and gas chromatographic product analysis. Evidence is gained that at $300 \mathrm{~K}$ only the stronger part of the Brønsted-acid sites are active in ethene oligomerization, while at increased temperatures more sites become active. On the contrary, in propene and isobutene oligomerization all sites are already active at $300 \mathrm{~K}$. This results in completely analogous products formed upon oligomerization of ethene, propene, and isobutene above $373 \mathrm{~K}$. The rate of oligomerization increases sharply with increasing reaction temperatures, resulting in a hindered transport of reactant molecules through the pores due to pore mouth blocking. The reactions on the outer surface become more important, which results in an increased branching of the oligomers formed at higher reaction temperatures. At $400 \mathrm{~K}$ cracking of the oligomers starts, and at $490 \mathrm{~K}$ the rate of cracking equals the rate of oligomerization. At this temperature desorption products show considerable branching, while at $573 \mathrm{~K}$ only highly branched products are desorbed. At temperatures above $500 \mathrm{~K}$ zeolite H-ZSM-5 becomes a dynamically operating catalytic system in the conversion of small olefins.
\end{abstract}

\section{INTRODUCTION}

In the reaction mechanism for the conversion of methanol into paraffins, olefins, and aromatics on zeolite H-ZSM-5, as we recently proposed (1), ethene and propene are expected to be the primarily formed olefins. The consecutive reactions of these olefins have been the subject of several investigations using conversion measurements $(2,3)$, thermogravimetry (TG) $(4,5)$, ir spectroscopy (4), and ${ }^{13} \mathrm{C}-\mathrm{NMR}$ spectroscopy (4-8). Important points of discussion that arise from these studies are: (i) the type of active site; (ii) the observed differences in reactivity towards ethene, propene, and isobutene; and (iii) the formation of linear or branched oligomers in low- and mediumtemperature reactions of small olefins. We consider these in turn.

(i) Type of active site. In order to explain the differences in the reactivity towards ethene, Rajadhyaksha and Anderson (9) proposed that H-ZSM-5 samples, prepared by $\mathrm{HCl}$ treatment, contain different active sites compared to samples prepared by $\mathrm{NH}_{4} \mathrm{NO}_{3}$ exchange. According to these authors, upon $\mathrm{HCl}$ treatment specific sites, obviously strong Lewis-acid sites, are created by dealumination of the crystal lattice. However, our data for ethene conversions on $\mathrm{H}-\mathrm{ZSM}-5$ samples subjected to $\mathrm{HCl}$, $\mathrm{HCl}-\mathrm{NH}_{4} \mathrm{Cl}$, and $\mathrm{NH}_{4} \mathrm{NO}_{3}$ treatment do not show significant differences with respect to the reactivity towards ethene.

Nevertheless, Lewis-acid sites are important in low-temperature reactions of olefins. Kubelkova et al. $(10,11)$ have shown that on $\mathrm{H}, \mathrm{Na}-\mathrm{Y}$ ethene can be oligomerized at $310 \mathrm{~K}$ only when strong Lewis-acid sites have been formed by dehydroxylation. On the other hand, propene can be oligomerized on Brønsted-acid sites. Karge (12) has shown that on the zeolite $\mathrm{H}$-mordenite (a solid which certainly contains no Lewisacid sites) ethene can be oligomerized only at $370 \mathrm{~K}$ and above on Brønsted-acid sites. Recently we reported data (5) that show 
that already at room temperature ethene can be oligomerized on Brønsted-acid sites in H-ZSM-5; when, however, Lewis-acid sites are also present the rate of oligomerization is enhanced. Novákova et al. (13) also report that on zeolite H-ZSM-5 ethene can be oligomerized on Brønsted-acid sites at room temperature.

(ii) Reactivity differences. In conversion experiments on zeolite H-ZSM-5 in which a poor reactivity towards ethene was reported $(6,14)$, propene and other small olefins could be readily converted. Also our data show (5) that at $300 \mathrm{~K}$ ethene oligomerizes slowly on zeolite H-ZSM-5, while propene and isobutene react very fast until the pore volume is almost completely filled with reaction products. In this paper new TG experiments will be presented in order to elucidate the temperature dependence of these oligomerization reactions. Furthermore, the differences in the rate of oligomerization of the olefins mentioned will be studied and its consequences for the transport of reactant and product molecules through the intracrystalline pores will be described.

(iii) Nature of oligomers. In the preceding paper $(8)$ we report new results obtained by high-resolution solid-state (HRSS) ${ }^{13} \mathrm{C}$ NMR spectroscopy on the oligomerization of ethene, propene, isobutene, and 2methyl-butene-1 on zeolite H-ZSM-5. These data give strong evidence that at $300 \mathrm{~K}$ in all cases only linear oligomers are formed. This result is unique for $\mathrm{H}-\mathrm{ZSM}-5$ when compared to the results of analogous oligomerization reactions on $\mathrm{H}-\mathrm{Y}(10,11)$ and $\mathrm{H}$-mordenite (12). After oligomeriza- tion of ethene on H-ZSM-5 at 373K some branched hydrocarbons were observed.

This result, together with the results of some desorption experiments of adsorbed oligomers, will be discussed in the context of the TG experiments mentioned above.

\section{EXPERIMENTAL}

Materials. The H-ZSM-5 samples were prepared according to previously described procedures (15) and were characterized by chemical analysis, $\mathrm{X}$-ray diffraction, and $n$ $\mathrm{C}_{4}$ adsorption (5). Prior to each experiment the zeolites were calcined in air at $823 \mathrm{~K}$ during $1 \mathrm{hr}$. The data are given in Table 1 .

Ethene, propene, and isobutene, used in TG experiments, were high-purity reagents $(99+\%)$ and were dried by molecular sieves before use. The vector gas $\mathrm{He}$ was purified by passing it successively over a BTS, Carbosorb, and molecular sieve column. In the ${ }^{13} \mathrm{C}$-NMR experiments $\mathrm{C}_{2} \mathrm{H}_{4}-1,2-{ }^{13} \mathrm{C}(90 \%$ enriched) from Stohler Isotope Chemicals was used.

TG experiments. A Cahn RG Electrobalance, fitted with a Eurotherm temperature programmer, was used, Prior to each experiment the zeolite samples were dehydrated at $673 \mathrm{~K}$ in a $\mathrm{He}$ flow $(200 \mathrm{ml} / \mathrm{min})$. The adsorption experiments were performed in continuous flow. The reactant $(40$ $\mathrm{ml} / \mathrm{min}$ ) was added to the He flow; at the same time the He flow was decreased proportionally to obtain a constant total gas flow $(200 \mathrm{ml} / \mathrm{min})$. In all experiments only chemisorption data are compared, i.e., after adsorption the sample is flushed in a $\mathrm{He}$ flow at reaction temperature in order to desorb the physisorbed material.

TABLE 1

Chemical Composition and Pore Volume of H-ZSM-5 Samples

\begin{tabular}{lccccccc}
\hline Sample & $\begin{array}{c}\mathrm{SiO}_{2} \\
(\mathrm{wt} \%)\end{array}$ & $\begin{array}{c}\mathrm{Al}_{2} \mathrm{O}_{3} \\
(\mathrm{wt} \%)\end{array}$ & $\begin{array}{c}\mathrm{Na}_{2} \mathrm{O} \\
(\mathrm{wt} \%)\end{array}$ & $\begin{array}{c}\mathrm{K}_{2} \mathrm{O} \\
(\mathrm{wt} \%)\end{array}$ & $\begin{array}{c}\mathrm{SiO}_{2} / \mathrm{Al}_{2} \mathrm{O}_{3} \\
\text { mole ratio }\end{array}$ & $\begin{array}{c}\text { No. B sites } \\
(\mathrm{mmol} / \mathrm{g})\end{array}$ & $\begin{array}{c}\text { Pore volume } \\
(\mathrm{ml} / \mathrm{g})\end{array}$ \\
\hline BII & 94.2 & 3.17 & 0.07 & 0.11 & 50.5 & 0.59 & 0.151 \\
GII & 88.3 & 4.48 & 0.37 & 0.37 & 33.5 & 0.70 & 0.126 \\
\hline
\end{tabular}


${ }^{13} \mathrm{C}-\mathrm{NMR}$ experiments. The spectra were obtained at ambient temperature in specially designed $10-\mathrm{mm}$ sample tubes at 22.6 $\mathrm{MHz}$ with a Bruker HX-90R spectrometer interfaced with a Digilab FTS-3 NMR pulsing and data system. The bandwidth was $5000 \mathrm{~Hz} .{ }^{2} \mathrm{H}_{6}$-acetone was used as an external reference.

Prior to adsorption the zeolites were evacuated $(0.13 \mathrm{~Pa})$ at $573 \mathrm{~K}$ for $1 \mathrm{hr}$. Ethene was adsorbed at $200 \mathrm{~K}$ and stored overnight at room temperature. After the $\mathrm{C}_{2} \mathrm{H}_{4}$ resonance in the spectrum had completely disappeared $(4,7)$ the sample tube was evacuated at $300 \mathrm{~K}$. Consecutively the sample tube was closed and the desorption was performed at the temperatures given in the text for $15 \mathrm{~min}$.

\section{RESULTS AND DISCUSSION}

It is known (5) that at $300 \mathrm{~K}$ ethene can be slowly oligomerized on zeolite H-ZSM-5, whereas propene and isobutene react much faster under these conditions. A temperature-programmed adsorption (TPA) of ethene (Fig. 1) shows that at slightly higher

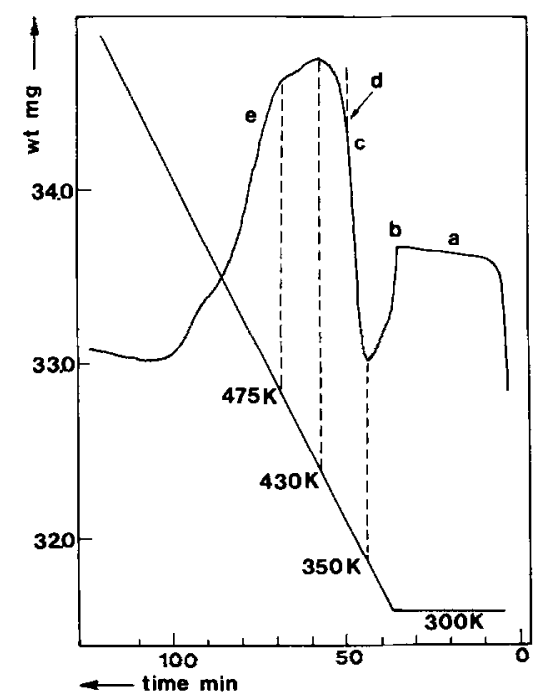

FIg. 1. Thermogravimetric curve of the temperature-programmed adsorption of ethene on zeolite $\mathrm{H}$ ZSM-5. (a) Physisorption + slow chemisorption at 300K. (b) Desorption of physisorbed ethene. (c) Fast chemisorption (oligomerization). (d) Start of cracking of the oligomers. (e) Fast cracking of oligomers. temperatures the oligomerization of ethene also becomes faster.

In Table 2 TG data are presented of adsorptions of several small olefins on zeolite H-ZSM-5 (sample BII) at different temperatures. From the amounts of adsorbed olefins it can be seen that at $293 \mathrm{~K}$ more propene and isobutene is adsorbed (about $95 \%$ of the pore volume is filled with oligomers) than ethene (only about $75 \%$ of the pore volume is filled). High-resolution solidstate (HRSS) ${ }^{13} \mathrm{C}$-NMR spectra of the oligomerization products of ethene, propene, and isobutene on zeolite H-ZSM-5 obtained at room temperature, reported in another paper $(8)$, show that in the case of ethene oligomerization linear paraffins are formed with a high average chain length (about $\mathrm{C}_{25}$ ), while upon oligomerization of propene and isobutene this average chain length was only $\mathrm{C}_{8}-\mathrm{C}_{12}$. Two points arise from these data: (i) shorter chains are more effective in filling the pore volume, and (ii) the difference in average chain length obtained after oligomerization at room temperature of ethene on the one hand and propene and isobutene on the other indicates that in ethene oligomerization only a small number of sites are active, apparently the most acid ones, whereas in propene and isobutene oligomerization more, if not all, sites may participate under these conditions.

In Fig. 2 the adsorption curves of ethene, propene, and isobutene adsorption at $373 \mathrm{~K}$, as well as the temperature-programmed desorption curves of the products formed, are depicted. It is shown that the rate of oligomerization as well as the products formed in these three experiments are similar. This indicates that the differences between ethene oligomerization and the oligomerization of propene and isobutene, observed at $298 \mathrm{~K}$, are no longer present at $373 \mathrm{~K}$, i.e., at $373 \mathrm{~K}$ in ethene oligomerization all sites are also active. It can be concluded now that the increase of the rate of oligomerization of ethene at increasing temperatures observed in Fig. 1 is not only due to an increase of the rate constant but also to an 


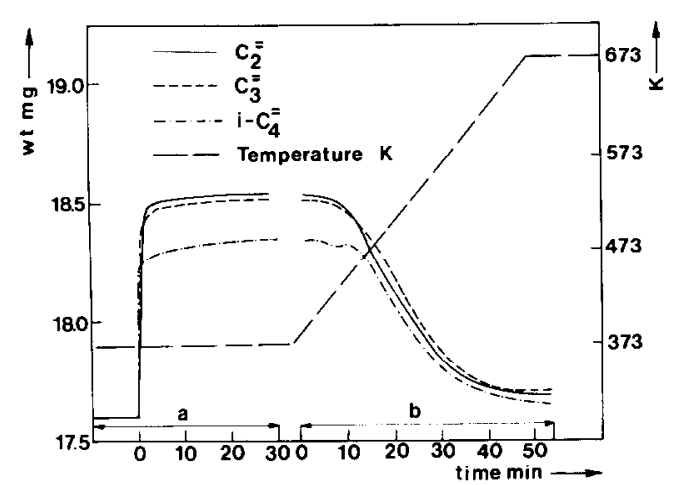

FIG. 2. Adsorption of small olefins at $373 \mathrm{~K}$ on zeolite H-ZSM-5 and temperature-programmed desorption in a He flow.

increase of the number of sites that participate in the reaction.

The HRSS- ${ }^{13} \mathrm{C}-\mathrm{NMR}$ spectrum recorded after adsorption of $\mathrm{C}_{2} \mathrm{H}_{4}$ at $373 \mathrm{~K}$ shows that the average chain length has become comparable to the chain length observed upon oligomerization of isobutene at $293 \mathrm{~K}(8)$. These results support the suggestion that under these conditions all Brønsted sites participate in the oligomerization reactions.

However, the chemisorption data (Table

2) also show that at increased adsorption temperatures the pore volume is less effectively filled by the formed oligomers. Moreover, in the HRSS $-{ }^{13} \mathrm{C}-\mathrm{NMR}$ spectrum of the ethene oligomer, formed at $373 \mathrm{~K}$, some branched products are observed. This indi-

TABLE 2

Maximum Chemisorption of Small Olefins ${ }^{a}$ on Zeolite H-ZSM-5 ${ }^{b}$

\begin{tabular}{|c|c|c|c|}
\hline $\begin{array}{l}\text { Ads. temp. } \\
\quad(\mathrm{K})\end{array}$ & $\begin{array}{c}\mathrm{C}_{2} \mathrm{H}_{4} \\
(\mathrm{mg} / \mathrm{g})\end{array}$ & $\begin{array}{c}\mathrm{C}_{3} \mathrm{H}_{6} \\
(\mathrm{mg} / \mathrm{g})\end{array}$ & $\begin{array}{l}\text { Isobutene } \\
(\mathrm{mg} / \mathrm{g})\end{array}$ \\
\hline 293 & $76(9.2)$ & $102(12.3)$ & $103(12.5)$ \\
\hline 323 & & 94 (11.4) & \\
\hline 373 & $81.3(9.8)$ & $81.2(9.8)$ & $59.7(7.2)$ \\
\hline
\end{tabular}

${ }^{a}$ The number in parentheses represents the average $\mathrm{C}$ number of chemisorbed oligomer per $\mathrm{ZO} \mathrm{H}^{+}$site, calculated as

$$
2 \times\left(\mathrm{C}_{2} \mathrm{H}_{4}\right)_{\mathrm{ads}}(\mathrm{mol} / \mathrm{g}) / \mathrm{Al} \text { sites }(\mathrm{mol} / \mathrm{g}) .
$$

${ }^{b}$ Sample BII. cates that at increased adsorption temperatures fast oligomerization and isomerization reactions on the outer surface become increasingly important, such that more branched products are formed, but also, and this is even more important, it indicates that the transport of reactant molecules through the intracrystalline pores may become hindered because of pore-mouth blocking. The data of Table 2 indicate that at higher temperatures $(373 \mathrm{~K})$ the effect of pore-mouth blocking becomes increasingly important in going from ethene to isobutene. This may be due to the fact that in the case of isobutene the initial tertiary carbenium ion can be formed more easily than the initial primary cation in the case of ethene. Especially for isobutene this may result in an increasing rate of oligomerization at the weak acid sites on the outer surface of the zeolite crystallites.

The TPA curve of ethene on zeolite $\mathrm{H}$ ZSM-5 shows that at about $400 \mathrm{~K}$ (d in Fig. 1) cracking of the initially formed oligomers begins. At about $440 \mathrm{~K}$ the point is reached where the rate of cracking becomes equal to the rate of oligomerization. At this point the amount of chemisorbed ethene reaches a maximum. These facts are in agreement with the conclusions of Derouane et al. (7) that the cracking of the oligomers starts at 413K. GLC analysis of products desorbed at $493 \mathrm{~K}$ showed mainly linear paraffins although amounts of branched paraffins were present in the mixture. Only small amounts of olefins could be detected.

HRSS- ${ }^{13} \mathrm{C}-\mathrm{NMR}$ spectra of the gaseous products desorbed at 493 and $573 \mathrm{~K}$, presented in Figs. 3a and b, respectively, clearly show that (i) only paraffins can be detected, and (ii) at $493 \mathrm{~K}$ linear and branched paraffins are desorbed with an average chain length of $\mathrm{C}_{46}\left(\mathrm{CH}_{2} / \mathrm{CH}_{3} \approx 1.7\right)$, while at $573 \mathrm{~K}$ only very short and highly branched paraffins $\left(\mathrm{CH}_{2} / \mathrm{CH}_{3} \approx 0.3\right)$ are desorbed. The observation, by GLC as well as by ${ }^{13} \mathrm{C}$-NMR spectroscopy, that cracking of the oligomerization products results in mainly paraffinic compounds suggests that 

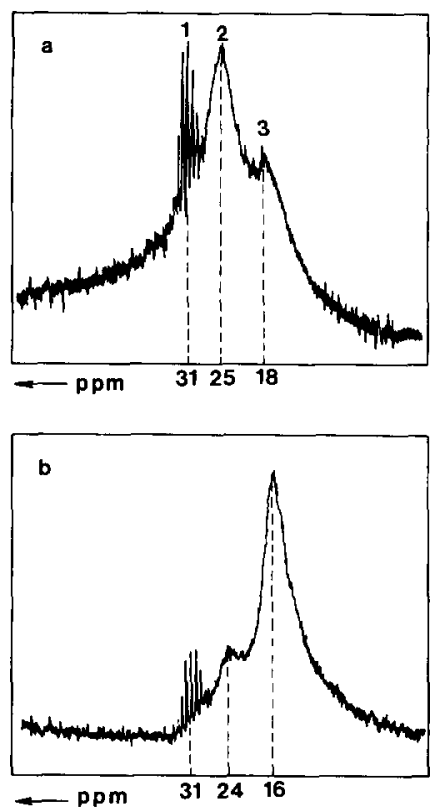

FIG. 3. High-resolution ${ }^{13} \mathrm{C}$-NMR spectra of decomposition products after cracking of the ethene oligomer. (a) Desorption temperature 493K; (b) desorption temperature $573 \mathrm{~K}$. ppm values compared to TMS. 1. ${ }^{2} \mathrm{H}_{6}$-acetone; 2 . $-\mathrm{CH}_{2}-; 3 .-\mathrm{CH}_{3}$.

olefins, once formed, are immediately hydrogenated or reoligomerized; this is in agreement with the conclusions of Derouane et al. (7).

\section{CONCLUSIONS}

Combination of the data reported in this paper and elsewhere $(4,5,7,8)$ shows that small olefins are very reactive towards zeolite H-ZSM-5. In order to understand the temperature dependence of this activity we have to distinguish three temperature regions:

1. $T<300 K$. Ethene is slowly oligomerized while propene and isobutene are converted rapidly. Only part of the active sites participate in the oligomerization of ethene. The reactions mainly occur inside the intracrystalline pores and consequently only linear oligomers are observed. The oligomerization products are very strongly adsorbed.

II. $300 K<T<500 K$. The rate of oligomerization per site (turnover number) in- creases for all reactants. Reactions on the most accessible sites, i.e., sites on the outer surface of the crystallites, are of increasing importance because the intracrystalline transport of reactant molecules may become hindered by pore-mouth blocking. This results in a decreasing maximum chemisorption with increasing temperature. The oligomerization reactions occur to a relatively increasing extent on the outer surface of the crystallites, resulting in the observation of some branched oligomers. Although cracking of the oligomers occurs at $T>400 \mathrm{~K}$ the residence time of the oligomerization products on the zeolite surface is long.

III. $T>500 K$. At these temperatures the rate of cracking of the oligomerization products becomes faster than the rate of oligomerization. Because of this, poremouth blocking by oligomers does not occur anymore and the transport of reactant molecules is no longer hindered. The residence time of the products in the zeolite becomes considerably shorter. In fact, starting with this temperature, zeolite $\mathrm{H}$ ZSM-5 becomes a dynamic catalytic operating system in the conversion of small olefins.

\section{ACKNOWLEDGMENTS}

The authors wish to thank J. W. de Haan and L. J. $M$. van de Ven for recording the ${ }^{13} \mathrm{C}$-NMR spectra. This work was supported by the Netherlands Foundation of Chemical Research (SON) with financial aid from the Netherlands Foundation for Pure and Scientific Research (ZWO).

\section{REFERENCES}

1. van den Berg, J. P., Wolthuizen, J. P., and van Hooff, J. H. C., "Proc. 5th Int. Conf. Zeolites" (L. V. C. Rees, Ed.), pp. 649-660. Heyden, London, 1980.

2. Ahn, B. J., Armando, J., Perot, G., and Guisnet, M., C.R. Acad. Sci. Paris Ser. C 288, 245 (1979).

3. Anderson, J. R., Mole, T., and Christov, V., J. Catal. 61, 477 (1980).

4. Bolis, V., Védrine, J. C., van den Berg, J. P., Wolthuizen, J. P., and Derouane, E. G., J. Chem. Soc. Faraday Trans. I 76, 1606 (1980). 
5. Wolthuizen, J. P., van den Berg, J. P., and van Hooff, J. H. C., "Catalysis by Zeolites" (B. Imelik et al., Eds.). pp. 85-92. Elsevier, Amsterdam, 1980.

6. Védrine, J. C., Dejaifve, P., Naccache, C., and Derouane, E. G., "Proc. Intern. Congr. Catalysis, 7th (Tokyo 1980)," pp. 724-738. Elsevier, Amsterdam, 1981.

7. Derouane, E. G., Gilson, J. P., and Nagy, J. B., J. Mol. Catal. 10, 331 (1981).

8. van den Berg, J. P., Wolthuizen, J. P., Clague, A. D. H., Hays, G., Huis, R., and van Hooff, J. H. C., J. Catal. 79, 000 (1983).

9. Rajadhyaksha, R. A., and Anderson, J. R., J. Catal. 63, 510 (1980).

10. Kubelkova, L., Novákova, J., Wichterlova, B., and Jíri̊, P., Coll. Czech. Chem. Comm. 45, 2290 (1980).
II. Kubelkova, L., Novákova, J., Dolejsek, Z., and Jírü, P., Coll. Czech. Chem. Comm. 45, 3101 (1980).

12. Karge, H. G., "Molecular Sieves II" (J. R. Katzer, Ed.). A.C.S. Symp. Ser., Vol. 40, pp. 584595 (1977).

13. Novákova, J., Kubelkova, L., Dolejsek, Z., and Jírů, P., Coll. Czech. Chem. Comm. 44, 3341 (1979).

14. Anderson, J. R., Foger, K., Mole, T., Rajadhyaksha, R. A., and Sanders, J. V., J. Catal. 58, 114 (1979).

15. Derouane, E. G., Dejaifve, P., Nagy, J. B., van Hooff, J. H. C., Spekman, B. P., Védrine, J. C., and Naccache, C., J. Catal. 53, (1978). 